\title{
Gendered disparities in take-ups of employee health benefits
}

\author{
Jennifer Reid Keene \\ University of Nevada, Las Vegas, jkeene@unlv.nevada.edu
}

Anastasia H. Prokos

lowa State University

Follow this and additional works at: https://digitalscholarship.unlv.edu/sociology_pubs

Part of the Family, Life Course, and Society Commons, Gender and Sexuality Commons, Health Policy Commons, and the Medicine and Health Commons

\section{Repository Citation}

Keene, J. R., Prokos, A. H. (2010). Gendered disparities in take-ups of employee health benefits.

Sociological Perspectives, 53(4), 503-526.

https://digitalscholarship.unlv.edu/sociology_pubs/7

This Article is protected by copyright and/or related rights. It has been brought to you by Digital Scholarship@UNLV with permission from the rights-holder(s). You are free to use this Article in any way that is permitted by the copyright and related rights legislation that applies to your use. For other uses you need to obtain permission from the rights-holder(s) directly, unless additional rights are indicated by a Creative Commons license in the record and/ or on the work itself.

This Article has been accepted for inclusion in Sociology Faculty Publications by an authorized administrator of Digital Scholarship@UNLV. For more information, please contact digitalscholarship@unlv.edu. 


\title{
GENDERED DISPARITIES IN TAKE-UPS OF EMPLOYEE HEALTH BENEFITS
}

\author{
JENNIFER REID KEENE \\ University of Nevada-Las Vegas \\ ANASTASIA H. PROKOS \\ Iowa State University
}

\begin{abstract}
Using a sample of 2,271 workers from the 2002 National Study of the Changing Workforce whose employers offered personal health insurance, this article investigates the gendered nature of health insurance benefit take-ups. These analyses include family and employment characteristics in addition to employers' contributions to health insurance premiums, a measure that is unexamined in sociological analyses of health benefits. Progressive logistic regression models predict the effects of gender and family characteristics. Results indicate that women with employed spouses are less likely to take up their own health benefits than are comparable men, net of basic employment characteristics. Gender differences disappear, however, when controlling for the level of employer contributions: women and men are equally likely to draw on their own employer's health benefits once we account for their out-of-pocket expense. The authors conclude that family contexts and employment structures jointly influence individuals' choices about their health benefits. The gendered structure of employment and, specifically, gendered patterns in employer contributions to health benefits are a better explanation for women's lower chances of benefit take-ups than gender relations within families.

Keywords: gender, health insurance, take-ups
\end{abstract}

As national debates about the availability and quality of healthcare in the United States rage on, sociologists must continue to examine and document disparities in access to and use of the most widely available type of healthcare coverage: employee health benefits. Research has consistently shown that the population of uninsured Americans has grown steadily from the late 1980s to the late 1990s (Holahan and Kim 2000) and that this trend has affected female and male workers differently (Lambrew 2001). However, less research grapples with the issue of why workers take up or turn down their own health benefits when benefits are available

Address correspondence to: Jennifer Reid Keene, 4505 S. Maryland Parkway, Box 455033, Las Vegas, NV 89154-5033; e-mail: jkeene@unlv.nevada.edu.

Sociological Perspectives, Vol. 53, Issue 4, pp. 503-526, ISSN 0731-1214, electronic ISSN 1533-8673.

(c) 2010 by Pacific Sociological Association. All rights reserved. Please direct all requests for permission to photocopy or reproduce article content through the University of California Press's Rights and Permissions website, at http://www.ucpressjournals.com/reprintinfo.asp. DOI: 10.1525/sop.2010.53.4.503. 
to them and how these patterns might vary by gender, family situation, and work characteristics.

Given the importance of health insurance for health outcomes and the fact that the majority of insured Americans obtain healthcare coverage through their employers, why would anyone turn down employer-provided health insurance benefits when such benefits are available? In this article, we consider contributions from two theories about determinants of employees' take-ups of their benefits. One theory invokes rational choice arguments and emphasizes the primacy of employment characteristics and employees' out-of-pocket costs (and generally ignores the influence of gender), and the other focuses on the gendered nature of workers' family relations and responsibilities, specifically relationships that are covered by insurance: spouses and children (and typically ignores the role of cost). While most research on this topic invokes one of these perspectives, we posit that they work in tandem to shape the decision-making context about health benefits. We also suggest that rational choice arguments are insufficient for understanding individual choices about health insurance take-ups, and instead these decisions must be understood within the context of gendered structures of employment and family life. Furthermore, because both employees' out-of-pocket costs and their family characteristics are embedded within the gendered institutions of work and family, we expect that those institutions mutually reinforce the construction of gender differences and gendered patterns in health insurance take-ups.

Employment characteristics, and particularly employees' out-of-pocket costs for their health benefits, are among the most salient determinants of take-ups (Cutler 2002). Economists have consistently shown that the less employees have to pay for their health benefits, the more likely they are to take up benefits (Blumberg, Nichols, and Banthin 2002). Yet employees may reject employers' offers if they have access through another source or if they determine that the cost of coverage outweighs the potential benefits. This might be especially the case for parents pursuing family coverage through their own health insurance benefits. Analyses that emphasize employment characteristics and costs as the primary determinants of take-ups take a rational choice perspective and focus on human capital and tend to treat employee's sex category as an external consideration and do not investigate how the patterns of the cost of benefits themselves may be gendered (cf., Cutler 2002). Furthermore, this research tends to ignore the gendered nature of family life and responsibilities and does not investigate how women's and men's differing family responsibilities relate to their employment experiences and may affect their access to and use of employee health benefits. The economic perspective is based on individualistic, human capital, and rational choice explanations for health insurance, while the sociological perspective emphasizes structural features of the labor market and individuals' positions within the labor market as determinants of access to health insurance (Kalleberg, Reskin, and Hudson 2000). This is not surprising given the neo-classical economic approach that emphasizes the interchangeability of workers and downplays the role of gendered social structures and patterns that reinforce gender inequality (Roos and Gatta 1999). 
Family life characteristics are the other main determinants of access to health benefits. For women, health insurance coverage is directly related to their family statuses as wives, widows, and mothers (Dewar 2000; Harrington Meyer and Pavalko 1996; Kaiser Family Foundation 2008; Montez, Angel, and Angel 2009) as well as their positions in the labor market as part- and full-time workers in an assortment of work arrangements (Dewar 2000; Jovanovic, Lin, and Chang 2003; Kalleberg et al. 2000; Wiatrowski 1995). Some studies have demonstrated that women are more likely than men to be covered as dependents than through their own employment (Abraham and Royalty 2005; Buchmueller 1996; Kaiser Family Foundation 2001; 2008). Research on family life characteristics does not examine employees' out-of-pocket costs for employer-provided health insurance. This omission is often due to data constraints (cf., Cubbins and Parmer 2001; Harrington Meyer and Pavalko 1996; Polsky, Stein, Nicholson, and Bundorf 2005) but also is related to the sociological focus on social structure rather than the specific economic characteristics of the health insurance package, the study of which has been dominated by economists.

Research on gender and employee benefits has established that the employment structure is gendered and that female and male workers occupy different positions in the labor market that affect their access to and use of health benefits (Dewar 2000; Glass 1990; Padavic and Reskin 2002; Reskin and Bielby 2005). In general, women are less likely than men to be employed in occupations and industries with health insurance benefits (Glass 1990; Padavic and Reskin 2002). It remains unclear, however, whether married women with access to their own benefits are more likely to decline them than are married men. Persistent labor market inequality and cultural expectations about women's work and careers may influence women to decline their own coverage more often than men do. Furthermore, and perhaps even more importantly, little sociological research on employee benefits has simultaneously scrutinized the gendered dynamics of family factors (marital status and parental status, for example) and gendered structural inequality in employment-related factors (such as firm size, full- or parttime status, or the out-of-pocket cost of benefits) for decisions to take up benefits when offered-a gap we seek to fill.

Our two primary research questions examine the interrelated aspects of gender relations within the family and the gendered structure of employment. The first asks whether the effect of family life characteristics on take-ups of health benefits is gendered. The second question is whether the gendered effects of family life (if any) persist once we account for the structural gender differences in employment characteristics and employees' out-of-pocket cost for health benefits. Sociological research has yet to simultaneously address how family, employment characteristics, and employers' contributions to premiums relate to workers' propensity to take up health benefits and whether these patterns vary by gender.

Attending to this void allows us to demonstrate how gender operates through the social institutions of work and family and affects workers' decisions about health benefits. The majority of research that examines health benefits access and take-ups has taken a rational choice perspective that treats gender as exogenous to work organizations-in keeping with other research that treats gender as an 
effect that can simply be separated from other effects (see Ely and Padavic 2007). In contrast, a rich body of feminist research demonstrates that gender operates within organizations, the labor market, and families (Glass 1990; Hays 1996; Padavic and Reskin 2002), which likely influences not only what benefits women and men have access to but also how they make decisions about those benefits.

We make three important contributions to this area of research. First, we investigate gendered patterns in the effects of family life factors controlling for the full range of the gendered employment contexts, including employers' contributions to health insurance premiums. This emphasis is in contrast to other research about gender and health insurance benefits that focuses exclusively on either family life or employment conditions and that, among sociologists, do not account for employees' out-of-pocket costs. Second, by limiting our analysis only to workers who were offered health benefits, we differentiate between workers who declined to take up benefits that were offered to them and those who do not have health benefits because they were not offered. This allows us to distinguish between take-ups and coverage of employer-provided health benefits, in contrast to most research that focuses primarily on coverage without regard to differences in workers' access to health benefits. Third, by using a sample of wage and salaried workers, we focus only on people who could potentially have access to the most common form of health insurance-employment-based. Furthermore, unlike employer-based data, these data are nationally representative and generalizable to the population of U.S. workers offered benefits.

\section{BACKGROUND}

\section{Access to and Take-Ups of Employer-Provided Health Insurance}

Currently most insured Americans have coverage through employers, either through their own job or a family member's (Fronstin 2008). For workers to be covered by employee health benefits, they must first be offered such insurance, and second they must have the resources to take up that benefit. Scholars have demonstrated that structural inequalities in the labor market ensure that workers do not have identical access to benefits (Glass 1990) and also do not have equal chances of accepting benefits when they are available (Fronstin 2008). Inequality in access and ability to take up benefits leads to unequal coverage and use.

Most analyses focus on one of three dimensions of health benefits: availability, coverage, or take-ups. Because workers' ability to take up benefits is predicated on their availability, in addition to other factors, we draw on studies that examine each of these three dimensions to guide our own analysis. In much of the research, availability, coverage, and take-ups are conflated because of data constraints, such that researchers are able to examine only one of these aspects of health benefits at a time. For example, some studies examine the receipt or source of health benefits without regard to availability of health insurance (cf., Cubbins and Parmer 2001; Harrington Meyer and Pavalko 1996; Polsky et al. 2005). Once these concepts are disentangled, previous explanations for variations in employee health insurance access and coverage are also likely to apply to differences in take-ups of health benefits. 
Recently, data from the Survey of Income and Program Participation demonstrates that between 1997 and 2002, workers were increasingly offered health benefits through their employers (70 percent in 1997 compared with 71.4 percent in 2002) and the percentage of those covered by such a plan also increased (60 percent in 1997 compared with 60.7 percent in 2002) (Fronstin 2005). During this period, however, workers were also more likely to decline coverage through their own employer even when offered such benefits. The percentage of workers who took up employee health benefits when offered declined from 85.7 percent in 1997 to 84.9 percent in 2002 . The majority (74 percent) of those who declined to take up their own benefits did so because they had coverage through someone else's insurance, although other respondents (about 22 percent) cited the high cost of their employers' plan as the reason why they declined coverage (Fronstin 2005). Other findings show that from 1999 to 2006, the percentage of employers offering health benefits declined from 66 percent to 61 percent and that the majority of the decline occurred among small businesses (Kaiser Family Foundation 2006).

\section{Gender, Family, and Employee Health Benefits}

Even though the majority of Americans receive their healthcare coverage through employers, sources of health insurance vary widely (Fronstin 2008) and are intertwined with gender and labor force experiences (Dewar 2000; Harington Meyer and Pavalko 1996; Kaiser Family Foundation 2008). One indicator of this gendered aspect is the upward trend in the number of uninsured women, which is growing at a faster pace than the number of uninsured men (Lambrew 2001). Gender differences in employer-provided health insurance are attributable in part to the types of jobs and industries in which women and men work. Enduring occupational and industrial segregation guarantees that women and men are concentrated in different occupations and jobs (Padavic and Reskin 2002), and this trend has consequences for their access to employer-based health insurance (Dewar 2000). Jobs dominated by women are considerably less likely to offer health benefits than male-dominated jobs (Dewar 2000; Glass 1990; Institute of Medicine 2002; Padavic and Reskin 2002). We do not yet know whether employment segregation may relate to differential take-ups of insurance, however.

Family patterns influence the sources through which workers have access to health insurance (including employer-provided benefits) as well as workers' propensity to take up benefits. Gender and family scholars also note the gendered nature of workers' family lives and document various ways in which women's and men's family and labor force experiences differ (Hays 1996; Padavic and Reskin 2002). Next, we draw on research that examines how marital status, spousal employment, and parenthood influence access, coverage, and take-ups of health insurance benefits.

Marriage is particularly salient because of the influence that spousal coverage may have on workers' decisions to take up insurance through their own employers. Research on health insurance benefits focuses on the influence of spousal employment, and not marital status per se. Importantly, one study showed that an overall decline in coverage from 1988 to 1997 was partly attributable to increases 
in workers opting for spousal coverage (despite increased offers of employer-provided health insurance during the same period) (Farber and Levy 2000). Other research by Polsky et al. (2005) has shown that married workers were more likely than singles to decline their own health benefits in favor of coverage through another source. During this period, single workers were more likely to be covered through their own employers (Polsky et al. 2005).

A different line of research has emphasized workers' decisions to take up offered health benefits by focusing only on dual-earner households. Among dual earners, being married improves both workers' access to employer-provided health benefits and the variety of health plan choices available to them (Abraham and Royalty 2005). Furthermore, among dual-earner couples, the decision to take up health benefits is related to both the price of workers' health plans and whether the couple has the opportunity to choose among plans from both spouses (Honig and Dushi 2004). Thus, the employment characteristics for each member of the couple may influence couple-level decisions about who takes up and who turns down insurance when it is available through their jobs.

Gender and marital status dually influence insurance coverage. Buchmueller (1996) found that among workers who were offered their own health benefits, women's lower coverage was largely related to a difference in coverage rates between married women and men. Much of the gender gap in health insurance coverage among married workers was due to married women's greater tendency to decline their own employee health benefits and opt for dependent coverage through their spouses' employers (Buchmueller 1996).

Harrington Meyer and Pavalko (1996:312, emphasis in original) stress the importance of women's family and employment roles over the life course in shaping coverage and suggest that "the interplay between family and work responsibilities may simultaneously limit women's eligibility for employment-based coverage and broaden women's options for alternative forms of insurance coverage." Among mature women in their study, those who were married were more likely to be insured as wives than as workers. In addition, unmarried women were two to three times more likely to be uninsured or to rely on public assistance. A recent study that extends Harrington Meyer and Pavalko's line of inquiry but applies it to Mexicanorigin women focused on the combination of employment and marital roles and found that it does, in fact, shape health insurance coverage among Mexican-origin, non-Hispanic White, and African American women (Montez et al. 2009). However, in contrast to other women, employment, marriage, or their combination does not automatically assure Mexican-origin women's health insurance coverage.

Researchers have inconsistently asked whether parents are more likely than nonparents to take up their own employer-provided health benefits when offered. Instead, studies have more often focused on documenting children's coverage rates (Fronstin 1999; Newacheck, Hughes, and Cisternas 1995; Weinick, Weigers, and Cohen 1998). Other research in this area shows a positive relationship between parents' education and the likelihood that children are privately versus publicly insured or uninsured altogether (Weinick et al. 1998). Furthermore, children living in two-parent families are more likely than others to be insured and to have private health insurance (Weinick et al. 1998). 
Research directly addressing the link between children's health insurance coverage and parents' decisions to take up or decline their own benefits is rare, despite the influence that family factors may exert on such decisions. One exception was a study of take-ups of employee benefits from 1996 to 1999 that found that having children in the family increased the likelihood that workers would decline their own benefits and take up coverage from another source (Polsky et al. 2005). Although not the primary focus of their research, the authors posited that this may be the result of increasing out-of-pocket costs for health benefits coupled with the greater likelihood of parents' eligibility for public sources of insurance when children are present in the home (Polsky et al. 2005). Their findings suggest this issue may be more relevant for low-income families than others.

Other research about the gendered nature of parenthood provides a basis for further study and suggests that decisions about health benefits are likely to be gendered. Although some research shows that men are increasing their share of household labor compared with previous generations (Bianchi, Milkie, Sawyer, and Robinson 2000), other work demonstrates the persistence of cultural norms requiring that women be intensive mothers and caregivers to their families, despite full-time employment (Hays 1996). In a qualitative study of contemporary fatherhood, Townsend (2002) shows the persistence of gendered expectations about fatherhood that require men to be husbands, breadwinners, homeowners, and fathers, and that these competing and, often contradictory, demands make emotionally involved, intensive fathering a difficult ideal to achieve. Similarly, in-depth research about highly successful employed women's challenges and decisions about negotiating work and family life also sheds light on how gendered expectations about career and motherhood influence women's choices and opportunities even as individual women try to reshape these terms (Blair-Loy 2003). As women and men navigate the competing demands of employment and family obligations, socially embedded expectations about men's and women's appropriate work and family roles are likely to influence their opportunities and decisions.

\section{Employment Characteristics}

Employer-provided health insurance benefits are not evenly distributed throughout the labor force (Glass 1990). Several employment characteristics predict health insurance coverage and the provision of fringe benefits in general, including firm size, unionization, sectoral location, occupation, and industry (Dewar 2000; Glass 1990; Seccombe 1993; Wiatrowski 1995). Seccombe (1993) found that larger firms and the presence of unions help ensure that employer-sponsored health insurance coverage is offered to employees. Regarding sectoral location and occupation, Wiatrowski (1995) concluded that public employees are more likely to have health benefits available to them than those in the private sector and that service workers are less likely to have health insurance through their employers than both white-collar and blue-collar workers. In addition, Wiatrowski (1995) demonstrated that retail trade and service industries are the least likely to offer health benefits. 


\section{Employer Contributions to Health Benefits}

Economic researchers have found that cost is workers' most prevalent reason for rejecting their own employer-provided health insurance when offered (Cutler 2002; Thorpe and Florence 1999). To our knowledge, no sociological studies account for the cost of health benefits or employer contributions to premiums in analyses of health benefits, despite evidence from the economic literature that these are important factors. Indeed, some research indicates that workers are more likely to decline their own health benefits when net premiums are higher (Polsky et al. 2005). However, out-of-pocket costs are a better explanation of workers' decisions to take up employee health benefits than are total premium costs (Blumberg et al. 2002; Cooper and Vistnes 2003). In addition, declines in take-ups of employee health benefits during the 1990s are associated with increases in employees' costs for coverage (Cutler 2002).

Cooper and Schone (1997) used data from the 1996 panel of the Medical Expenditure Panel Survey (MEPS) and the 1987 National Medical Expenditure Survey (NMES) and investigated declines in the availability and take-ups of employerprovided health insurance. They documented that more firms offered employee health benefits in 1996 than in 1987, however less workers elected to take their employer-based coverage. The authors posited various reasons for these declines in take-ups including declining real incomes, the increasing costs of health insurance, less generous benefits packages from employers, and increases in employee premiums for health benefits (Cooper and Schone 1997). Recent research by Fronstin (2005) found support for this same trend during the period from 1997 to 2002 .

Overall, the literature on employer-provided health benefits draws on both economic and sociological research, both of which have their limitations. Rational choice explanations posited by economists, which emphasize human capital characteristics, need to be supplemented with the large sociological literature about gendered social institutions. Previous efforts to understand insurance takeups assume that gender is exogenous to organizations and that gender has effects that can be isolated (see Ely and Padavic 2007). Instead, we argue that family and work institutions reproduce gendered patterns in health insurance benefit take-ups. Workers' decisions about health benefits are made within work and family contexts that have deeply embedded assumptions about gender. In turn, sociological analyses ignore the economic constraints associated with employers' contributions and employees' out-of-pocket costs-factors that are central to our analysis.

\section{HYPOTHESES}

This study explores how family life factors relate to workers' take-ups of health benefits, controlling for employment characteristics and employers' contributions to health benefit premiums. We posit three sets of research hypotheses. Hypotheses 1 and 2 address the relationship of family factors to take-ups, Hypotheses 3 and 4 address the way that gender affects the relationship between family factors 
and take-ups, and Hypotheses 5 and 6 address the effect of employment characteristics on the relationship between gender, family factors, and take-ups.

Hypothesis 1: Married workers with employed spouses are less likely to take up their health benefits than both married workers who do not have employed spouses and unmarried workers.

We expect this to be the case because married workers with employed spouses are more likely to have access to health insurance through their spouses' employment.

Hypothesis 2: Parents have greater chances of taking up their own health benefits than nonparents.

This is likely because in order to be eligible for family coverage employees must also take up their personal benefits; thus, workers with children might opt to take up benefits in pursuit of family and dependent coverage.

Hypothesis 3: Among women, having an employed spouse has a stronger negative effect on take-ups than among men.

In keeping with previous research demonstrating married women's lower likelihood to take up their insurance (Buchmueller 1996), we expect that women with employed spouses are even less likely than men with employed spouses to take up employer-provided health insurance.

Hypothesis 4: The effect of parental status is gendered. While all parents will be motivated to take up benefits in order to gain access to coverage for their children, fathers will be more likely to take up than mothers.

We expect this because the persistence of traditional gender expectations will encourage men to take up their benefits as part of their responsibility as family breadwinners, along with the U.S. emphasis on health insurance as a component of employment.

Hypothesis 5: Controlling for occupational characteristics will partially mediate the effects of family life factors and gender that we explored in the previous models.

Specifically, we expect that the difference between mothers' and fathers' chances of taking up benefits will be smaller once we control for occupational characteristics and that the difference between women and men with employed spouses will also be smaller with occupational controls. Previous research has demonstrated the salience of structural work characteristics for gender differences in workers' take-ups; therefore, these may influence what amounts to couple-level decisions about take-ups.

Hypothesis 6: Controlling for workers' reports of their employers' contributions to health insurance premiums (an indicator of affordability and quality of the benefit package for workers) will further decrease the influence of the effects of gender and marital status examined in previous models. 
We expect this to be the case because economic studies have shown that employees' out of pocket cost is among the strongest predictors of employee's decisions to take up health benefits.

\section{DATA, MEASURES, AND ANALYTIC APPROACH}

\section{Data and Sample}

We use data from the 2002 National Study of the Changing Workforce (NSCW), which is a study of the work and personal/family lives of the U.S. workforce. The NSCW survey was developed by the Families and Work Institute, and data were collected through telephone interviews with workers (Families and Work Institute 2004). The NSCW includes a substantial number of respondents $(n=2,810)$ and the analytic sample for this article consists of 2,271 employed individuals who indicated that health benefits were available to them through their own employers. The NSCW survey is an appropriate data source for the present analyses because it contains information about employees' work and family characteristics and information about fringe benefits including eligibility for and use of employee health benefits. Furthermore, it contains indicators of employers' contributions to health insurance premiums. As recommended by the Families and Work Institute, for the regression analysis we employ the weight provided with the survey for use with the 2002 data in order to adjust for unequal probabilities of inclusion in the sample.

\section{Measures}

Take-Ups of Health Benefits. The dependent variable is a dichotomous measure indicating whether or not the respondent is covered by their employer's health insurance plan, which we refer to as "take-ups" of personal health insurance. Questions about take-ups were asked only of those respondents who answered affirmatively that their health benefits were available to them through their employers. Responses were coded 1 if respondents took up benefits.

Sex Category. Respondent's sex category is captured by a dummy variable coded 1 for female.

Family Status. Family life characteristics, specifically marriage and parenthood, are meant to indicate other potential sources of healthcare coverage as well as family responsibilities. Marital status is captured by a three-category variable indicating if the respondent is married with an employed spouse, married with a non-employed spouse, or single (reference category). Parental status is a dummy variable coded 1 if they have children younger than 18 at home.

Employment. Employment characteristics include the respondent's salary, work hours, industry, occupation, firm size, union membership, and public or private employment sector. Salary is indicated by the respondent's logged yearly salary. Workers are coded 1 for part-time if they worked fewer than 35 hours in the past week. Industry is indicated by a set of five dummy variables grouping various industries together in accordance with previously established conventions (Fronstin 2008). Each dummy variable is coded 1 for the following: manufacturing, 
construction, and agriculture; business and professional services; wholesale and retail trade; and financial, insurance, and real estate. All other services including health, educational, and social services are combined in the reference category.

Respondent's occupation is measured by seven dummy variables indicating separate groups of occupations in accordance with coding and grouping conventions set by previous studies (Galinsky and Bond 1998). Each dummy variable is coded 1 for the following groups: top or mid-level manager, executive, or administrator; professional positions; technical positions; sales; administrative support; and service position. Other occupations including machine operator, skilled or manual labor, and farming, forestry, or fishing constitute the reference category.

Five dummy variables indicate the national number of employees at the respondent's firm: less than 25, 25-49, 50-99, and 100-499 (500 or more is the reference category)..$^{1}$ A dummy variable indicates whether the respondent belongs to a labor union (coded 1) and a final dummy variable designates whether the respondent is a public employee (coded 1).

Human Capital. We control for human capital because of its link to employment characteristics. For these analyses, the primary indicator of human capital is respondent's education. Level of education is measured by a set of dummy variables each coded 1 if the respondent has less than a high school diploma, a high school diploma, and more than a bachelor's (some college or a bachelor's degree is the reference category). Job tenure is captured by the number of years with the current employer.

Employer Contributions. Employee cost is the most influential factor predicting whether workers take up health benefits when offered (Cutler 2002). We measure the level of employer contributions to health benefits using three dummy variables. The first indicates whether the respondent reports that the cost of health insurance is partly paid by the employer. The second captures whether the respondent reports that none of the cost is paid by the employer. The third variable is coded 1 if the response indicated "don't know." The omitted category of employer contributions captures respondents who indicated that the costs are fully paid by the employer.

Demographics. We use several demographic control variables. Ethnoracial categories are captured by a series of dummy variables. Each is coded 1 for Hispanic, African-American, and other ${ }^{2}$ ethnoracial groups (White is the reference category). These are the most refined race categories that the survey would allow us to delineate. Age is a continuous variable measured in years.

\section{Analysis Plan}

Recall that our primary research question focuses on the gendered effects of family life features on take-ups of health benefits controlling for occupational factors. To investigate these relationships, we begin by modeling the relationship between gender and family factors for take-ups and then examine the persistence of those effects after controlling for occupational factors and employer contributions to insurance premiums. 
We use logistic regression models to test our hypotheses. Model 1 regresses the odds of benefit take-ups on gender, family characteristic variables, and controls for basic demographics (age and ethnoracial status) to examine the main effects of gender and marital status on benefit take-ups (Hypotheses 1 and 2). Model 2 adds interaction terms between gender and family characteristic variables (marital status and parental status) to the equation in order to address Hypotheses 3 and 4. The next model includes human capital and occupational variables to determine whether the observed influence of family characteristics persists once differences in human capital and employment situations are taken into account (Hypothesis 5). Finally, Model 4 tests Hypothesis 6 by including indicators of employers' contribution to premiums in the model. In short, if the effects of marital status, gender, and parental status in Models 1 and 2 are no longer statistically significant in Model 3, then we can attribute differences in take-ups across workers' types of families to differences in human capital characteristics and occupational situations. If, by Model 4, differences in take-ups disappear, then the level of employer contributions to health insurance premiums is responsible.

\section{Results}

Table 1 presents descriptive statistics for women and men and shows that women are less likely to take up their personal health benefits than are men (79 percent and 85 percent, respectively). Women and men also differ in their family and work characteristics. Regarding family life, men are more likely than women to be parents and to be married to a spouse who is not in the labor force, and women are more likely to be single. In the paid work sphere, it is not surprising to find that women and men are concentrated in different industries, occupations, and firms of different sizes. Finally, women and men differ little regarding employer contributions to health insurance premiums; the only statistically significant difference is that women are more likely to be unsure of whether and how much their employer pays toward their premiums.

Although these bivariate results indicate no gender differences in how much employers pay toward premiums, men's and women's reports of how much employers contribute to insurance costs vary by parental and marital status. For example, among women, those who are not married are more likely than other women to have no employer contribution to premiums (results not shown). Also, proportionally more fathers' employers pay part of their insurance costs than mothers' (results not shown). These trends suggest that we have cause to investigate gendered patterns of the influence of costs on take-ups. Women and men in this sample are similar in terms of their demographic characteristics, except that men's earnings are slightly higher, on average, and women tend to have more education. We now turn to multivariate results.

Table 2 shows logistic regression results predicting the likelihood of take-ups by our key independent and demographic control variables. Model 1 is the baseline that includes gender, marital and parental statuses, and basic demographic characteristics. This model indicates that both family status and gender have statistically significant effects on workers' odds of taking up employer-provided health 
TABLE 1

Descriptive Statistics for Variables Used in the Analysis, by Gender ${ }^{a}$

\begin{tabular}{|c|c|c|c|c|}
\hline & $\begin{array}{l}\text { Full Sample } \\
(\mathrm{N}=2,344)\end{array}$ & $\begin{array}{c}\text { Men } \\
(n=1,022)\end{array}$ & $\begin{array}{c}\text { Women } \\
(n=1,322)\end{array}$ & $\begin{array}{c}\text { Men-Women } \\
\text { Difference }\end{array}$ \\
\hline $\begin{array}{l}\text { Dependent Variable } \\
\text { Takes up health benefits }\end{array}$ & $82 \%$ & $85 \%$ & $79 \%$ & $6 \%$ *** \\
\hline $\begin{array}{l}\text { Family Status } \\
\text { Married, spouse employed } \\
\text { Married, spouse not employed } \\
\text { (Not married) } \\
\text { Parent to child under } 18\end{array}$ & $\begin{array}{l}46 \% \\
14 \% \\
40 \% \\
44 \%\end{array}$ & $\begin{array}{l}45 \% \\
21 \% \\
34 \% \\
46 \%\end{array}$ & $\begin{array}{c}48 \% \\
7 \% \\
45 \% \\
42 \%\end{array}$ & $\begin{array}{c}-3 \% \\
14 \%{ }^{* * *} \\
-11 \% * * \\
4 \% *\end{array}$ \\
\hline $\begin{array}{l}\text { Demographics } \\
\text { Age (mean) } \\
\text { Ethnoracial Category } \\
\text { Black } \\
\text { Hispanic } \\
\text { Other race } \\
\text { (White) }\end{array}$ & $\begin{array}{c}10 \% \\
8 \% \\
5 \% \\
76 \%\end{array}$ & $\begin{array}{c}10 \% \\
9 \% \\
5 \% \\
76 \%\end{array}$ & $\begin{array}{c}11 \% \\
7 \% \\
5 \% \\
76 \%\end{array}$ & $\begin{array}{c}-1.00^{*} \\
-2 \% \\
1 \% \\
0 \% \\
0 \%\end{array}$ \\
\hline $\begin{array}{l}\text { Employment Characteristics } \\
\text { Part-time worker (full-time) } \\
\text { Industry } \\
\text { Manufacturing, construction, agriculture } \\
\text { Professional services } \\
\text { Wholesale and retail trade } \\
\text { Financial, insurance, and real estate } \\
\text { (Other industry) } \\
\text { Logged yearly salary }\end{array}$ & $\begin{array}{c}34 \% \\
7 \% \\
15 \% \\
6 \% \\
38 \% \\
11(.79)\end{array}$ & $\begin{array}{c}4 \% \\
46 \% \\
8 \% \\
15 \% \\
4 \% \\
26 \% \\
11(.76)\end{array}$ & $\begin{array}{c}12 \% \\
19 \% \\
5 \% \\
15 \% \\
9 \% \\
51 \% \\
10(.78)\end{array}$ & $\begin{array}{c}-8 \% * * * \\
27 \% * * * \\
3 \% * * \\
0 \% \\
-5 \% * * * \\
-25 \% * * * \\
.33^{* * *}\end{array}$ \\
\hline $\begin{array}{l}\text { Human Capital } \\
\text { Education } \\
\text { Less than high school diploma } \\
\text { High school diploma } \\
\text { (Some college or BA) } \\
\text { More than BA degree } \\
\text { Years with current employer }\end{array}$ & $\begin{array}{c}7 \% \\
31 \% \\
30 \% \\
32 \% \\
8(.09)\end{array}$ & $\begin{array}{c}10 \% \\
32 \% \\
29 \% \\
30 \% \\
9(.09)\end{array}$ & $\begin{array}{c}5 \% \\
29 \% \\
31 \% \\
35 \% \\
8(.08)\end{array}$ & $\begin{array}{l}5 \% \text { \%** } \\
3 \% \\
-2 \% \\
-5 \% * * \\
1.00^{* *}\end{array}$ \\
\hline $\begin{array}{l}\text { Occupation } \\
\text { Top/mid-level manager, executive, administrator } \\
\text { Professional positions } \\
\text { Technical positions } \\
\text { Sales } \\
\text { Administrative support } \\
\text { Service position } \\
\text { (Other occupation) }\end{array}$ & $\begin{array}{c}15 \% \\
21 \% \\
4 \% \\
8 \% \\
15 \% \\
9 \% \\
27 \%\end{array}$ & $\begin{array}{c}14 \% \\
18 \% \\
4 \% \\
7 \% \\
7 \% \\
9 \% \\
41 \%\end{array}$ & $\begin{array}{c}17 \% \\
25 \% \\
5 \% \\
9 \% \\
24 \% \\
10 \% \\
10 \%\end{array}$ & $\begin{array}{c}-3 \% * \\
-8 \% * * * \\
-1 \% \\
-3 \% * \\
-16 \% * * * \\
-1 \% \\
31 \% * * *\end{array}$ \\
\hline $\begin{array}{l}\text { Firm size } \\
<25 \text { employees } \\
25-49 \text { employees } \\
50-99 \text { employees } \\
\text { 100-499 employees } \\
\text { (500+ employees) } \\
\text { Union member (non-union) } \\
\text { Public employee (private) }\end{array}$ & $\begin{array}{c}12 \% \\
7 \% \\
9 \% \\
20 \% \\
52 \% \\
21 \% \\
24 \%\end{array}$ & $\begin{array}{c}13 \% \\
7 \% \\
8 \% \\
18 \% \\
54 \% \\
24 \% \\
21 \%\end{array}$ & $\begin{array}{c}12 \% \\
8 \% \\
9 \% \\
22 \% \\
50 \% \\
19 \% \\
26 \%\end{array}$ & $\begin{array}{c}1 \% \\
-1 \% \\
0 \% \\
-5 \% \%^{* *} \\
4 \% * \\
5 \% \text { \%* } \\
-5 \% \\
\end{array}$ \\
\hline $\begin{array}{l}\text { Employer Contributions } \\
\text { Employer pays nothing } \\
\text { Employer pays part } \\
\text { (Employer pays fully) } \\
\text { Don't know if employer pays }\end{array}$ & $\begin{array}{c}6 \% \\
67 \% \\
24 \% \\
3 \%\end{array}$ & $\begin{array}{c}6 \% \\
68 \% \\
25 \% \\
2 \%\end{array}$ & $\begin{array}{c}7 \% \\
66 \% \\
24 \% \\
5 \%\end{array}$ & $\begin{array}{c}-1 \% \\
2 \% \\
1 \% \\
-3 \% * * *\end{array}$ \\
\hline
\end{tabular}

a Sample size represents unweighted data. All descriptive statistics are based on weighted data. ${ }^{*} p<.05 ; * * p .01 ;{ }^{* * *} p<.001$. 
insurance. In support of Hypothesis 1, the odds of taking up benefits are 48 percent lower if workers are married to an employed spouse than if they are single (percentage change $\left.=\left(e^{b}-1\right) \times 100\right)$, controlling for demographics. In addition, women's odds of taking up benefits are 40 percent less than men's odds of takeups. The results do not support the expectation that parents have greater chances of taking up benefits than non-parents (Hypothesis 2) because the coefficient for the parent variable is not statistically significant.

Recall that Hypothesis 3 proposed that, among women, having an employed spouse has a stronger negative effect on take-ups than it does among men. To test this hypothesis, we now turn to Model 2. This model includes interaction effects between female and family status variables (both marital status and parental status), still controlling for respondents' demographic characteristics. Results in this model support Hypothesis 3. Indeed, the interaction term (Female $\times$ Married, spouse employed) has a statistically significant negative coefficient $(b=-.78)$. This effect means that the negative effect of being married to an employed spouse on take-ups is stronger among women, and the odds of take-ups among women who are married to an employed spouse are 54 percent lower than the odds for comparable men. Notably, the main effects for both "married, spouse employed" and "woman" are not statistically significant. In this model, the coefficient for being married with an employed spouse represents the difference between being married to an employed spouse and being unmarried among men (the omitted gender category) and it is no longer significant once we include the interaction terms between gender and marital status. With the inclusion of the interaction terms, the lack of statistical significance of the main effects indicates that the effect of marital status we observed in Model 1 is really an effect of differences between women and men across marital and parental statuses. Furthermore, the lower odds of take-ups among women that we observed in Model 1 can be attributed to the combination of marital status and parental status, because the significant interactions in Model 2 indicate that women's odds of take-ups are lower than men's only when they are married or a parent.

Model 2 also allows us to test Hypothesis 4 concerning the proposed interaction between gender and parental status. The statistically significant negative coefficient for the interaction term between woman and parent indicates that, indeed, mothers have lower odds of taking up their personal health benefits than fathers. In fact, for men, the effect of being a parent is positive $(b=.38, p<.05)$, which means that fathers' odds of taking up benefits are 47 percent greater than men who are not parents. The effect of being a parent is negative among women (combining the main effect of parent with the coefficient for Woman $\times$ Parent), indicating that mothers are less likely than women without children to take up their health benefits.

To illustrate the findings pertaining to the significant interaction effects, we present predicted probabilities for women and men by their family statuses. We calculated the predicted probabilities based on the coefficients in Model 2 (with all control variables set to their means). The first trend to notice is that married men are much more likely to take up their health benefits than married women regardless of their spouses' employment status. Married men with employed spouses 
TABLE 2

Logistic Regression Predicting Odds of Health Benefit Take-Ups on Gender, Family Status, and Controls

\begin{tabular}{|c|c|c|c|c|}
\hline & \multicolumn{2}{|c|}{ Model 1} & \multicolumn{2}{|c|}{ Model 2} \\
\hline & $b$ & $\operatorname{Exp}(B)$ & $b$ & $\operatorname{Exp}(B)$ \\
\hline Woman & $\begin{array}{l}-.51^{* * *} \\
(.12)\end{array}$ & .60 & $\begin{array}{c}.23 \\
(.21)\end{array}$ & 1.25 \\
\hline \multicolumn{5}{|l|}{ Family Status } \\
\hline Married, spouse employed & $\begin{array}{l}-.65^{* * *} \\
(.14)\end{array}$ & .52 & $\begin{array}{c}-.20 \\
(.21)\end{array}$ & .82 \\
\hline Married, spouse not employed & $\begin{array}{c}.07 \\
(.23)\end{array}$ & 1.08 & $\begin{array}{c}.43 \\
(.29)\end{array}$ & 1.54 \\
\hline Parent of child under 18 & $\begin{array}{c}.14 \\
(.12)\end{array}$ & 1.15 & $\begin{array}{l}.38^{*} \\
(.19)\end{array}$ & 1.47 \\
\hline \multicolumn{5}{|l|}{ Demographics } \\
\hline Age & $\begin{array}{l}.03^{* * *} \\
(.01)\end{array}$ & 1.03 & $\begin{array}{l}.03^{* * *} \\
(.01)\end{array}$ & 1.03 \\
\hline \multicolumn{5}{|l|}{ Ethnoracial category ${ }^{\mathrm{b}}$} \\
\hline Black & $\begin{array}{c}-.13 \\
(.19)\end{array}$ & .88 & $\begin{array}{c}-.15 \\
(.19)\end{array}$ & .86 \\
\hline Hispanic & $\begin{array}{c}-.18 \\
(.21)\end{array}$ & .83 & $\begin{array}{c}-.18 \\
(.21)\end{array}$ & .83 \\
\hline Other race & $\begin{array}{c}.26 \\
(.28)\end{array}$ & 1.30 & $\begin{array}{c}.22 \\
(.28)\end{array}$ & 1.24 \\
\hline \multicolumn{5}{|l|}{ Interaction Terms } \\
\hline Woman $\times$ Spouse employed & & & $\begin{array}{l}-.78^{* *} \\
(.26)\end{array}$ & .46 \\
\hline Woman $\times$ Spouse not employed & & & $\begin{array}{c}-.89^{*} \\
(.45)\end{array}$ & .41 \\
\hline Woman $\times$ Parent & & & $\begin{array}{r}-.52^{*} \\
(.25)\end{array}$ & .59 \\
\hline Constant & $\begin{array}{l}.84^{* * * *} \\
(.23)\end{array}$ & 2.33 & $\begin{array}{l}.57^{*} \\
(.24)\end{array}$ & 1.76 \\
\hline Chi-square & \multicolumn{2}{|c|}{$74.55^{* * *}$} & \multicolumn{2}{|c|}{$19.43^{* * *}$} \\
\hline Model chi-square & \multirow{2}{*}{\multicolumn{2}{|c|}{8}} & \multicolumn{2}{|c|}{$93.98^{* * *}$} \\
\hline$d f$ & & & \multicolumn{2}{|c|}{11} \\
\hline$-2 \log$ likelihood & \multicolumn{2}{|c|}{1,928} & \multicolumn{2}{|c|}{1,909} \\
\hline
\end{tabular}

a Omitted category of marital status is "not married."

${ }^{\mathrm{b}}$ Omitted ethnoracial category is White.

${ }^{*} p<.05 ;{ }^{* *} p<.01 ;{ }^{* *} p<.001$. 
TABLE 3

Predicted Probabilities of Women's and Men's Take-Ups of Health Benefits by Family Status

\begin{tabular}{lcc}
\hline & Women & Men \\
\hline Married, spouse employed & .71 & .84 \\
Married, spouse not employed & .80 & .91 \\
Unmarried & .87 & .87 \\
Parent & .78 & .89 \\
Non-parent & .81 & .84 \\
\hline
\end{tabular}

are 13 percent more likely to take up their benefits than comparable women, and even among married people whose spouses are not employed, men are 11 percent more likely to take up benefits. In contrast, the probability of taking up health benefits is identical for unmarried women and men. The second important finding is parental status has opposite effects for women related to men. Specifically, being a parent decreases women's chances of taking up their own health benefits by 3 percent but increases men's chances by 5 percent. Furthermore, fathers are 11 percent more likely to take up their own health benefits than mothers ( 89 and 78 percent, respectively), although among non-parents, men are only slightly more likely than women to take up their health benefits.

Do women's lower odds of take-ups persist after controlling for important employment characteristics? In short, the results are mixed. Hypothesis 5 predicted that occupational characteristics and employer's contribution would have strong mediating effects on the relationships found in previous models. Model 3 adds human capital and employment characteristics to the model. Once we control for employment-related variables, the interaction between gender and marital status remains statistically significant and, consistent with results in the previous model, offers further support for Hypothesis 3.

It is also notable that, with the inclusion of human capital and employment variables in Model 3, the Woman $\times$ Parent interaction term is no longer significant. This means that the difference between mothers and fathers in their likelihood of take-ups that we found in Model 2 is explained by differences in their human capital and occupational attributes. In fact, the effect of parenthood itself has no significant effect net of the work characteristics added to this model.

The final model adds indicators of employers' contribution to employees' health benefit costs, measures that sociologists have not examined. The amount an employer contributes to the cost of benefits (and whether or not the employee is aware of this contribution) has a strong predictive relationship with whether workers take up their health benefits. In support of Hypothesis 6, the odds of taking up benefits are substantially lower when employers contribute nothing to the cost of benefits, pay for only part of the cost, and when a worker does not know whether employers contribute to the cost of health benefits than when employers pay the full cost. This finding is consistent with economic research that highlights the salience of employees' out-of-pocket costs for take-ups of health benefits. Furthermore, once we control for employer contributions in this model, the interaction 
TABLE 4

Logistic Regression Predicting Odds of Take-Ups of Health Benefits on Gender, Family Status, and Controls

\begin{tabular}{|c|c|c|c|c|}
\hline & \multicolumn{2}{|c|}{ Model 3} & \multicolumn{2}{|c|}{ Model 4} \\
\hline & $B$ & $\operatorname{Exp}(B)$ & $B$ & $\operatorname{Exp}(B)$ \\
\hline Women & $\begin{array}{c}.38 \\
(.23)\end{array}$ & 1.46 & $\begin{array}{c}.28 \\
(.26)\end{array}$ & 1.32 \\
\hline \multicolumn{5}{|l|}{ Family Status } \\
\hline Married, spouse employed & $\begin{array}{c}-.51^{*} \\
(.22)\end{array}$ & .60 & $\begin{array}{l}-.93^{* * *} \\
(.24)\end{array}$ & .39 \\
\hline Married, spouse not employed & $\begin{array}{c}.23 \\
(.31)\end{array}$ & 1.26 & $\begin{array}{c}-.01 \\
(.33)\end{array}$ & .99 \\
\hline Parent of child under 18 (non-parent) & $\begin{array}{l}.17 \\
(.20)\end{array}$ & 1.19 & $\begin{array}{c}.27 \\
(.21)\end{array}$ & 1.31 \\
\hline \multicolumn{5}{|l|}{ Demographics } \\
\hline Age & $\begin{array}{c}.00 \\
(.01)\end{array}$ & 1.00 & $\begin{array}{c}.00 \\
(.01)\end{array}$ & 1.00 \\
\hline \multicolumn{5}{|l|}{ Ethnoracial category ${ }^{\mathrm{b}}$} \\
\hline Black & $\begin{array}{c}.06 \\
(.21)\end{array}$ & 1.07 & $\begin{array}{l}-.06 \\
(.22)\end{array}$ & .95 \\
\hline Hispanic & $\begin{array}{c}-.10 \\
(.22)\end{array}$ & .91 & $\begin{array}{c}-.12 \\
(.25)\end{array}$ & .89 \\
\hline Other race & $\begin{array}{l}.06 \\
(.31)\end{array}$ & 1.06 & $\begin{array}{c}.46 \\
(.36)\end{array}$ & 1.59 \\
\hline \multicolumn{5}{|l|}{ Interaction Terms } \\
\hline Woman $\times$ Spouse employed & $\begin{array}{r}-.63^{*} \\
(.28)\end{array}$ & .53 & $\begin{array}{c}-.26 \\
(.30)\end{array}$ & .77 \\
\hline Woman $\times$ Spouse not employed & $\begin{array}{c}-.52 \\
(.48)\end{array}$ & .59 & $\begin{array}{l}-.27 \\
(.52)\end{array}$ & .76 \\
\hline Woman $\times$ Parent & $\begin{array}{c}-.32 \\
(.27)\end{array}$ & .73 & $\begin{array}{c}-.43 \\
(.28)\end{array}$ & .65 \\
\hline \multicolumn{5}{|l|}{ Employment Characteristics } \\
\hline $\begin{array}{l}\text { Part-time worker (full-time) } \\
\text { Industry }\end{array}$ & $\begin{array}{l}-1.58^{* * *} \\
(.20)\end{array}$ & .21 & $\begin{array}{c}-1.43^{* * *} \\
(.21)\end{array}$ & .24 \\
\hline Manufacturing, construction, agriculture & $\begin{array}{c}.43^{*} \\
(.21)\end{array}$ & 1.54 & $\begin{array}{c}.47^{*} \\
(.22)\end{array}$ & 1.60 \\
\hline Professional services & $\begin{array}{c}-.15 \\
(.26)\end{array}$ & .86 & $\begin{array}{c}.02 \\
(.28)\end{array}$ & 1.02 \\
\hline Wholesale and retail trade & $\begin{array}{c}-.24 \\
(.22)\end{array}$ & .79 & $\begin{array}{c}-.22 \\
(.23)\end{array}$ & .80 \\
\hline Financial, insurance, real estate & $\begin{array}{c}-.21 \\
(.27)\end{array}$ & .81 & $\begin{array}{c}-.18 \\
(.29)\end{array}$ & .83 \\
\hline \multicolumn{5}{|l|}{ Occupation } \\
\hline Top/mid-level manager, executive, administrator & $\begin{array}{c}.15 \\
(.26)\end{array}$ & 1.17 & $\begin{array}{c}.10 \\
(.27)\end{array}$ & 1.10 \\
\hline Professional position & $\begin{array}{c}-.03 \\
(.26)\end{array}$ & .97 & $\begin{array}{c}-.07 \\
(.28)\end{array}$ & .94 \\
\hline Technical position & $\begin{array}{l}.77 \\
(.43)\end{array}$ & 2.17 & $\begin{array}{l}.98^{*} \\
(.46)\end{array}$ & 2.65 \\
\hline Sales & $\begin{array}{c}-.09 \\
(.28)\end{array}$ & .91 & $\begin{array}{c}.11 \\
(.31)\end{array}$ & 1.12 \\
\hline Administrative support & $\begin{array}{c}-.25 \\
(.23)\end{array}$ & .78 & $\begin{array}{c}-.25 \\
(.25)\end{array}$ & .78 \\
\hline Service position & $\begin{array}{c}-.32 \\
(.25)\end{array}$ & .73 & $\begin{array}{c}-.28 \\
(.27)\end{array}$ & .75 \\
\hline
\end{tabular}




\section{TABLE 4}

Logistic Regression Predicting Odds of Take-Ups of Health Benefits on Gender, Family Status, and Controls (Continued)

\begin{tabular}{|c|c|c|c|c|}
\hline & \multicolumn{2}{|c|}{ Model 3} & \multicolumn{2}{|c|}{ Model 4} \\
\hline & $B$ & $\operatorname{Exp}(B)$ & $B$ & $\operatorname{Exp}(B)$ \\
\hline \multicolumn{5}{|l|}{ Firm size f $^{\mathrm{f}}$} \\
\hline Less than 25 employees & $\begin{array}{l}-.45^{*} \\
(.19)\end{array}$ & .64 & $\begin{array}{c}-.51^{*} \\
(.20)\end{array}$ & .60 \\
\hline 25-49 employees & $\begin{array}{l}-.60^{* *} \\
(.23)\end{array}$ & .55 & $\begin{array}{l}-.69^{* *} \\
(.24)\end{array}$ & .50 \\
\hline 50-99 employees & $\begin{array}{l}-.52^{*} \\
(.22)\end{array}$ & .59 & $\begin{array}{r}-.54^{*} \\
(.24)\end{array}$ & .58 \\
\hline 110-499 employees & $\begin{array}{l}-.29 \\
(.17)\end{array}$ & .75 & $\begin{array}{l}-.26 \\
(.18)\end{array}$ & .77 \\
\hline Union member & $\begin{array}{l}.41^{*} \\
(.20)\end{array}$ & 1.50 & $\begin{array}{l}.23 \\
(.21)\end{array}$ & 1.26 \\
\hline Public employee & $\begin{array}{l}.20 \\
(.19)\end{array}$ & 1.22 & $\begin{array}{l}.23 \\
(.20)\end{array}$ & 1.26 \\
\hline Logged yearly salary & $\begin{array}{l}.16^{*} \\
(.08)\end{array}$ & 1.17 & $\begin{array}{l}.13 \\
(.08)\end{array}$ & 1.13 \\
\hline \multicolumn{5}{|l|}{$\begin{array}{l}\text { Human Capital } \\
\text { Education }^{c}\end{array}$} \\
\hline Less than a high school diploma & $\begin{array}{l}-.38 \\
(.26)\end{array}$ & .68 & $\begin{array}{c}-.12 \\
(.28)\end{array}$ & .89 \\
\hline High school diploma & $\begin{array}{l}-.02 \\
(.16)\end{array}$ & .98 & $\begin{array}{l}.10 \\
(.17)\end{array}$ & 1.10 \\
\hline More than a BA degree & $\begin{array}{l}.45^{*} \\
(.19)\end{array}$ & 1.57 & $\begin{array}{l}.38 \\
(.19)\end{array}$ & 1.46 \\
\hline Years with current employer & $\begin{array}{l}.07^{* * *} \\
(.01)\end{array}$ & 1.07 & $\begin{array}{l}.06^{* * *} \\
(.01)\end{array}$ & 1.07 \\
\hline \multicolumn{5}{|l|}{ Employer contributions to premiumsg } \\
\hline Employer makes no contribution & & & $\begin{array}{c}-2.33^{* * *} \\
(.27)\end{array}$ & .10 \\
\hline Employer makes partial contribution & & & $\begin{array}{l}-.72^{* * *} \\
(.20)\end{array}$ & .49 \\
\hline Employee does not know & & & $\begin{array}{c}-3.39^{* * * *} \\
(.38)\end{array}$ & .03 \\
\hline Constant & $\begin{array}{l}-.22 \\
(.88)\end{array}$ & .80 & $\begin{array}{l}1.01 \\
(.94)\end{array}$ & 2.76 \\
\hline Chi-square & \multicolumn{2}{|c|}{$230.57^{* * *}$} & \multicolumn{2}{|c|}{$154.62^{* * *}$} \\
\hline $\begin{array}{l}\text { Model chi-square } \\
d f\end{array}$ & \multicolumn{2}{|c|}{$324.55^{* * *}$} & \multicolumn{2}{|c|}{$479.17^{* * *}$} \\
\hline-2 log likelihood & \multicolumn{2}{|c|}{$1,678.3$} & \multicolumn{2}{|c|}{$\begin{array}{c}36 \\
1,523.685\end{array}$} \\
\hline
\end{tabular}

a Omitted marital status category is "not married."

bOmitted ethnoracial category is "White."

"Omitted category of education is "some college or BA."

dOmitted industry category is "all other industries."

eOmitted occupation category is "other occupation."

f Omitted firm size category is "500 or more employees."

g Omitted category of employer contributions is "employer pays full."

${ }^{*} p<.05 ;{ }^{* *} p<.01 ;{ }^{* *} p<.001$. 
between gender and marital status is no longer statistically significant, and among married women and men with employed spouses, the odds of taking up benefits are the same. Men and women with an employed spouse have 60 percent lower odds of take-ups than those who are not married, which is consistent with previous research.

\section{Discussion and Conclusion}

The present study examines how gender, family status, and employer contributions to premiums relate to workers' take-ups of their personal health insurance benefits. Our findings support the idea that gender differences exist in the relationship between spousal employment and take-ups as well as parental status and take-ups. Paid work characteristics explain differences between mothers and fathers but do not fully explain gender differences in the effects of spousal employment on workers' propensities to take up their health benefits. Employer contributions, which have a strong predictive relationship to take-ups of health benefits, mediate the gender differences in the effects of spousal employment on take-ups. Nonetheless, spousal employment remains a salient predictor.

A great deal of previous research led us to posit gender differences in take-ups of benefits. Not only are women less likely to be in a position to be offered benefits (Glass 1990), but previous research suggested that married women are more likely to decline their own health insurance coverage than others (Buchmueller 1996). Indeed, our results showed that among workers with employed spouses, women were less likely than men to take up benefits. Importantly, after controlling for labor market characteristics and employers' contributions to premiums, the interaction effect between gender and spousal employment was no longer significant, indicating that, net of labor market characteristics and employer contributions to premiums, women and men made similar decisions concerning health benefit take-ups. We are careful not to suggest, however, that women and men have identical experiences concerning employer-provided personal health benefits. Instead we argue that, given the same structural conditions, women and men act similarly rather than differently, and it is those gendered structural conditions, and not gender as an individual characteristic or gender only as part of a family dynamic, that most relate to outcomes.

Previous findings about gender differences in health benefits assume that characteristics of individual women and men in the workplace shape their choices. Our findings demonstrate that this inequality is larger than individual people and is instead related to how work and family institutions themselves are gendered and how that dynamic operates to perpetuate gender inequality in health benefit takeups. This calls into question rational choice models that treat gender as exogenous and ignore the gendered contexts in which workers make their decisions about benefits. Indeed, what appear to be gendered family choices are better explained as employment constraints that serve to reinforce gendered family dynamics. Specifically, because women are in positions of being with different access to employer-paid coverage, families make the "decision" to go without women's employers' coverage. This in turn reconstructs family dynamics that privilege men's role as 
"family providers." Based on our analysis, we argue that both family contexts and employment structures are salient and they jointly influence the choices individuals make about their health insurance benefits.

The results regarding the effect of spousal employment are notable and lend credence to previous research that has found marital status to be a salient predictor of insurance coverage (Harrington Meyer and Pavalko 1996). While other research has focused on the importance of spousal coverage for women's access to insurance, changes in the labor market and declines in take-ups overall suggest that this option may become increasingly crucial for both women and men. Importantly, our results indicated that for all workers spousal employment has a negative relationship to benefit take-up, suggesting that marriage to an employed spouse offers a safety net of sorts allowing people to opt for potentially better or less costly health insurance coverage.

Few studies examine the influence of parental status on workers' decisions to take up their own coverage. Based on the scant literature on this topic, we had expected that all parents would be more likely than non-parents to take up benefits. Instead we found that parental status influenced mothers' and fathers' likelihoods of take-ups in opposite ways. While fathers were more likely to take up benefits than non-parents, mothers were less likely. We suggest that this is the result of gender differences in employment characteristics, which account for the effects we found. Among women, the lower chances that mothers will take up their own benefits than women without children could be more evidence of a "motherhood penalty" that affects women's wages and job opportunities (Correll, Benard, and Paik 2007). In addition, women's lower odds of benefit take-up may be influenced by state health insurance programs that offer coverage to children. Mothers, who are likely to be in lower income brackets and qualify for such programs, may forgo their own insurance to avoid premium costs, while still having their children covered through the state. The data we use do not allow us to test for these possibilities, and we suggest that others may be able to identify data sources that could be used to investigate this possibility.

Consistent with economists' analyses, our results indicate that employers' contributions to health insurance premiums strongly influence workers' take-ups. Workers who report that they are entirely responsible for the costs of their health benefits are far less likely to elect coverage than those whose employers make a contribution of any size. In exploratory analyses, we tested for interactions between gender and level of employer contribution and found no significant differences between women and men. This lack of a gender difference provides more evidence that economic imperatives, such as the out-of-pocket costs of health insurance, encourage women and men to make similar decisions about their health benefits.

Several limitations of this study merit discussion. Although we emphasize the influence of spousal employment, we must also note that this is of course different from knowing whether workers actually had access to insurance through their spouses. Spousal employment is only a proxy for such access, and the dataset did not allow us to know whether respondents actually had or used such access. 
Data that could address workers' multiple options for personal benefits, as well as multiple sources of coverage, could alter our interpretations.

It is also important to note the selectivity of our sample. By limiting the sample to only those workers who were offered benefits, we disproportionately eliminated women from the sample, because only 78 percent of women were offered benefits versus 85 percent of men. This sample selectivity means that we examined take-up decisions among only the most privileged workers, and men are overrepresented in this group. Thus, it would be a mistake to infer that the same factors influence coverage rates for women and men, because benefit coverage is necessarily tied to the availability of benefits.

We should also acknowledge the difficulty in accurately measuring employer contributions to health insurance premiums using employee-based data. In our study, this measure is based on respondents' self-reports, and so it is arguably capturing not what the employer actually contributes to premiums but rather respondents' perceptions of employer contributions. Although there may be a gap between workers' reports and their employers' actual contributions, we suggest that in making decisions about whether to take-up their health insurance benefits, perceptions of employers' contributions may be more important than what employers actually contribute. Related to the issue of measuring premiums, 67 respondents reported they "don't know" whether or how much their employer contributes to their premiums and these respondents were more likely to be women. Because employees' perceptions of cost are part of what our measures capture, we chose to include the "don't know" category as a separate category for analyses for exactly this reason. Since health plan documentation is often obtuse, verbose, and overwhelming, it is possible that employees do not understand how much their employer pays but instead make decisions based on other sources of advice such as coworkers.

We use cross-sectional data in this study, and this limits our ability to make causal inferences about predictors of health benefit take-ups. Since we cannot control for the time order of some of our predictor variables (e.g., becoming a parent or a spouse's employment status), we want to acknowledge that employees' decisions about health benefits may change annually in response to changes in their family lives. However, we cannot control for these changes using cross-sectional data. We argue, nonetheless, that our findings do illustrate the relationships between our key predictor variables and health benefit take-ups at a single point in time and do provide insight into how the gendered nature of family life and employment relate to take-ups.

Employer-provided insurance is still the primary avenue through which Americans obtain health insurance coverage. Some research focuses on access; the majority of research examines coverage; and we propose that it is also important to begin examining issues of quality. In the present study, measures of employer contributions act as one proxy for the quality of health benefits. We recognize, however, that this indicator reflects employers' ability or willingness to offer benefits rather than the quality of the healthcare coverage itself. The bigger issue of quality that is at stake is whether insurance coverage, once obtained, meets workers' specific 
personal and familial needs. These needs may include things such as the extent of health coverage, the choice of providers, coverage of particular medical procedures or prescription medications, and the limits or benefits of dual coverage. All of these factors may also be related to the form of the benefit package, including whether it is a Health Maintenance Organization (HMO), Preferred Provider Organization (PPO), or Point of Service (POS).

Marital and parental statuses appear to be additional mechanisms through which healthcare inequality is maintained and may have a lasting impact on health outcomes. It is well established that traditional axes of stratification such as gender, race, and class contribute to inequalities in access to health benefits and healthcare (Cubbins and Parmer 2001; Keene and Prokos 2007) and to overall health (Institute of Medicine 2002; Williams 1999; Williams and Collins 1995). A less understood dynamic is how family characteristics help to maintain healthcare inequality. Indeed, the ways in which the family as a social institution interacts with other social institutions (such as healthcare and the workplace) reproduces various types of social inequality.

These differences across families highlight the larger problems associated with the employment-based system of health insurance in the United States. Other research has established that labor force inequality influences the availability of health benefits across occupations and industries and that this necessarily relates to take-ups. Furthermore, the salience of employers' contributions to take-ups in our analysis and in other research implies that when employers increasingly shift the costs of health benefits to workers, families have to adjust. Whereas some families can endure rising out-of-pocket costs, others may have to forgo coverage altogether or seek public sources of health insurance.

Sociologists must continue to examine disparities in health insurance using social indicators such as family status and labor market status while at the same time drawing on the strengths of economic models that take employees' outof-pocket costs into account. Our research highlights the fact that existing data and research on health insurance suffers from two major limitations that should be addressed in future research and data collection. First, research must make distinctions between access and take-ups of insurance in order to better identify their unique sets of predictors. Second, studies need to develop and use more sophisticated and comprehensive indicators of quality and cost. Attending to these issues will enable researchers to paint a clearer picture of the structural inequality that is perpetuated through our national reliance on employer-based healthcare coverage and potentially make stronger arguments for alternative models of health insurance.

\section{NOTES}

1. Respondents were asked how many people worked for their company. If the respondent's work location was the only location, we used the number of employees at his or her local place of work.

2. The NSCW does not allow us to specify which "other" ethnoracial groups are included in this category. 


\section{REFERENCES}

Abraham, Jean Marie and Anne Beeson Royalty. 2005. “Does Having Two Earners in the Household Matter for Understanding How Well Employer-Based Health Insurance Works?" Medical Care Research and Review 62(2):167-86.

Bianchi, Suzanne M., Melissa A. Milkie, Liana C. Sawyer, and John P. Robinson. 2000. "Is Anyone Doing the Housework? Trends in the Gender Division of Labor." Social Forces 79(1):191-228.

Blair-Loy, Mary. 2003. Competing Devotions: Career and Family among Women Executives. Cambridge, MA: Harvard University Press.

Blumberg, Linda J., Len M. Nichols, and Jessica S. Banthin. 2002. "Worker Decisions to Purchase Health Insurance." International Journal of Health Care Finance and Economics 1(3/4):305-25.

Buchmueller, Thomas C. 1996. "Marital Status, Spousal Coverage, and the Gender Gap in Employer-Sponsored Health Insurance." Inquiry 33(4):308-16.

Cooper, Philip F. and Barbara Steinberg Schone. 1997. "More Offers, Fewer Takers for Employment-Based Health Insurance: 1987 and 1996." Health Affairs 16(6):142-49. - and Jessica Vistnes. 2003. “Workers' Decisions to Take-Up Offered Health Insurance Coverage: Assessing the Importance of Out-of-Pocket Premium Costs." Medical Care 41(7 Suppl.):III35-III43.

Correll, Shelley J., Stephen Benard, and In Paik. 2007. "Getting a Job: Is There a Motherhood Penalty?" American Journal of Sociology 112(5):1297-338.

Cubbins, Lisa A. and Penelope Parmer. 2001. "Economic Change and Health Benefits: Structural Trends in Employer-Based Health Insurance." Journal of Health and Social Behavior 42(1):45-63.

Cutler, David M. 2002. "Employee Costs and the Decline in Health Insurance Coverage." Working Paper, National Bureau of Economic Research, Cambridge, MA.

Dewar, Diane M. 2000. "Gender Impacts on Health Insurance Coverage: Findings for Unmarried Full-Time Employees." Women's Health Issues 10(5):268-77.

Ely, Robin and Irene Padavic. 2007. "A Feminist Analysis of Organizational Research on Sex Differences." Academy of Management Review 32(4):1121-43.

Families and Work Institute. 2004. National Study of the Changing Work force: Guide to Public Use Files. Families and Work Institute: New York.

Farber, Henry S. and Helen Levy. 2000. "Recent Trends in Employer-Sponsored Health Insurance Coverage: Are Bad Jobs Getting Worse?" Journal of Health Economics 19(1): 93-119.

Fronstin, Paul. 1999. "Employment-Based Health Insurance for Children: Why Did Coverage Increase in the Mid-1990s?" Health Affairs 18(5):131-36.

—. 2005. "Employment-Based Health Benefits: Trends in Access and Coverage." EBRI Issue Brief No. 284.

- 2008. "Sources of Health Insurance and Characteristics of the Uninsured: Analysis of the March 2008 Current Population Survey." EBRI Issue Brief No. 321.

Galinsky, Ellen and James T. Bond. 1998. The 1998 Business Work-Life Study. New York: Families and Work Institute.

Glass, Jennifer. 1990. "The Impact of Occupational Segregation on Working Conditions." Social Forces 68(3):779-96.

Harrington Meyer, Madonna and Eliza K. Pavalko. 1996. "Family, Work, and Access to Health Insurance among Mature Women." Journal of Health and Social Behavior 37(4):311-25.

Hays, Sharon B. 1996. The Cultural Contradictions of Motherhood. New Haven, CT: Yale University Press. 
Holahan, John and Johnny Kim. 2000. "Why Does the Number of Uninsured Americans Continue to Grow?" Health Affairs 19(4):188-96.

Honig, Marjorie and Irena Dushi. 2004. "Household Demand for Health Insurance: Price and Spouse's Coverage." U.S. Department of Labor, Employee Benefits Security Administration.

Institute of Medicine. 2002. Care without Coverage: Too Little, Too Late. Washington, DC: National Academy Press.

Jovanovic, Zorana, Chyongchiou J. Lin, and Chung-Chou H. Chang. 2003. “Uninsured Vs. Insured Population." Journal of Health and Social Policy 17(3):71-85.

Kaiser Family Foundation. 2001. Fact Sheet: Women's Health Insurance Coverage. http:/ / www. kff.org/uninsured/upload/Women-s-Health-Insurance-Coverage-Fact-Sheet.pdf . 2006. Employer Health Benefits: 2006 Survey of Findings. Menlo Park, CA: Henry J. Kaiser Family Foundation.

. 2008. Fact Sheet: Women's Health Insurance Coverage. http://www.kff.org/womenshealth/upload/6000_07.pdf

Kalleberg, Arne L., Barbara F. Reskin, and Ken Hudson. 2000. "Bad Jobs in America: Standard and Nonstandard Employment Relations and Job Quality in the United States." American Sociological Review 65(2):256-78.

Keene, Jennifer R. and Anastasia H. Prokos. 2007. "Comparing Offers and Take-Ups of Employee Health Insurance across Race, Gender, and Decade." Sociological Inquiry 77(3):423-58.

Lambrew, Jeanne M. 2001. “Diagnosing Disparities in Health Insurance for Women: A Prescription for Change." New York: The Commonwealth Fund.

Montez, Jennifer Karas, Jacqueline L. Angel, and Ronald J. Angel. 2009. "Employment, Marriage and Inequality in Health Insurance for Mexican-Origen Women." Journal of Health and Social Behavior 50(2):132-48.

Newacheck, Paul W., Dana C. Hughes, and Miriam Cisternas. 1995. “Children and Health Insurance: An Overview of Recent Trends." Health Affairs 14(1):244-54.

Padavic, Irene and Barbara F. Reskin. 2002. Women and Men at Work. Thousand Oaks, CA: Pine Forge Press.

Polsky, Daniel, Rebecca Stein, Sean Nicholson, and M. Kate Bundorf. 2005. "Employer Health Insurance Offerings and Employee Enrollment Decisions." Health Services Research 40(5):1259-78.

Reskin, Barbara F. and Denise D. Bielby. 2005. "A Sociological Perspective on Gender and Career Outcomes." Journal of Economic Perspectives 19(1):71-86.

Roos, Patricia and Mary Lizabeth Gatta. 1999. "The Gender Gap in Earnings: Trends, Explanations, and Prospects." Pp. 95-123 in Handbook of Gender and Work, edited by G. Powell. Thousand Oaks, CA: Sage.

Seccombe, Karen. 1993. “Employer Sponsored Medical Benefits: The Influence of Occupational Characteristics and Gender." The Sociological Quarterly 34(4):557-80.

Thorpe, Kenneth E. and Curtis S. Florence. 1999. "Why Are Workers Uninsured? EmployerSponsored Health Insurance in 1997." Health Affairs 18(2):213-18.

Townsend, Nicholas. 2002. The Package Deal: Marriage, Work, and Fatherhood in Men's Lives. Philadelphia: Temple University Press.

Weinick, Robin M., Margaret E. Weigers, and Joel D. Cohen. 1998. “Children's Health Insurance, Access to Care, and Health Status: New Findings." Health Affairs 17(2):127-36.

Wiatrowski, William J. 1995. "Who Really Has Access to Employer-Provided Health Benefits?" Monthly Labor Review 118(6):36-44.

Williams, David R. 1999. "Race, Socioeconomic Status, and Health: The Added Effects of Racism and Discrimination." Annals of the New York Academy of Sciences 896(December):173-88. and Chiquita Collins. 1995. "U.S. Socioeconomic and Racial Differences in Health: Patterns and Explanations." Annual Review of Sociology 21(August):349-86. 